\title{
Short communication: Analysis of association between the prion protein (PRNP) locus and milk traits in Latxa dairy sheep
}

\author{
Z. G. Vitezica, $\left.{ }^{*}\right\rceil \ddagger^{1}$ I. Beltran de Heredia, $\S$ and E. Ugarte \\ *INRA, UMR 1289, Tissus Animaux Nutrition Digestion Ecosystème et Métabolisme, F-31326 Castanet-Tolosan, France \\ †Université de Toulouse, INPT, UMR 1289, Tissus Animaux Nutrition Digestion Ecosystème et Métabolisme, ENSAT, F-31326 Castanet-Tolosan, \\ France \\ ҒENVT, INPT, UMR 1289, Tissus Animaux Nutrition Digestion Ecosystème et Métabolisme, F-31076 Toulouse, France \\ $\S N e i k e r$ Tecnalia, Basque Institute of Agricultural Research and Development, Campus Agroalimentario de Arkaute, Apdo. 46, \\ 01080 Vitoria-Gasteiz, Spain
}

\begin{abstract}
The purpose of this study was to analyze associations between polymorphisms in the PRNP gene and ewe milk traits. A total of 242,565 lactations of the Latxa breed were used. Milk, fat and protein yields, and fat and protein content from black-faced Latxa from Spanish Basque Country, black-faced Latxa from Navarra, and blond-faced Latxa were collected. To evaluate evidence of association, the different traits were analyzed using an animal model, where the PRNP genotype effect was included or not as a random effect. Adding the PRNP effect to the model improved the fitting for milk yield in black-faced Latxa from Spanish Basque Country and in blond-faced Latxa, for fat yield in black-faced Latxa from Navarra, and for protein yield in blond-faced Latxa. However, the proportion of the phenotypic variance explained by the $P R N P$ effect for milk yield $\left(1.0 \times 10^{-3}\right)$, fat yield $\left(3.6 \times 10^{-3}\right)$ and protein yield $\left(9.4 \times 10^{-4}\right)$ were near zero. The $P R N P$ locus accounts for about $0.5,1.5$, and $0.4 \%$ of total genetic (PRNP and polygenic) variance in milk, fat, and protein yield. These values indicated that the PRNP effect is not relevant regarding genetic additive contribution. For breeding purposes, it is unlikely that selection for scrapie resistance will have an effect on the milk traits studied in the Latxa breed.
\end{abstract}

Key words: association analysis, milk trait, PRNP gene, sheep

\section{Short Communication}

Scrapie susceptibility is mainly controlled by polymorphisms at the PRNP gene (Hunter et al., 1996). Several point mutations exist at codons 136 (A, V), 154 $(\mathrm{R}, \mathrm{H})$, and $171(\mathrm{R}, \mathrm{Q}, \mathrm{H})$ of the gene. Five haplotypes

Received January 12, 2013.

Accepted May 23, 2013.

${ }^{1}$ Corresponding author: zulma.vitezica@ensat.fr are the most commonly found in the literature (ARR, ARQ, AHQ, ARH, and VRQ). For classical scrapie, the ARR haplotype is mainly associated with resistance and the VRQ haplotype is associated with susceptibility (Hunter et al., 1996; Elsen et al., 1999; Díaz et al., 2005).

The Latxa breed is a dairy sheep composed by 3 strains. The skin color distinguishes blond-faced and black-faced. Morphological differences divide blackfaced into 2 strains: animals from Spanish Basque Country and animals from Navarre. Each strain has its own breeding program, but the 3 of them are focused mainly on improvement of milk yield. Since 2003, selection for scrapie resistance has been implemented for Latxa breeding programs. In the case of Latxa, the starting point of this selection process was not favorable. Less than $7 \%$ of animals were homozygous for the resistant haplotype ARR (Hurtado et al., 2002); however, the incidence of scrapie cases was very rare. Therefore, in order not to compromise the ongoing selection program for milk yield, a slow selection program based on eliminating the VRQ haplotype instead of increasing the frequency of the ARR haplotype was started. Preliminary studies on 3,000 genotyped animals were conducted to assess the effect of the PRNP locus on production traits. The results indicated no evidence of association between the PRNP genotypes and the milk traits (Legarra et al., 2004). However, this study included a small amount of data, and a potential bias in the sampling procedure of animals to be genotyped. After almost $10 \mathrm{yr}$ of selection for scrapie resistance in Latxa breed, the number of genotyped animals is 10 times higher than in the beginning of the selection program due to the systematic genotyping of selection candidates and replacement animals. No other study about the relationship between the $P R N P$ gene and milk traits has been done until now for the different Latxa strains.

Studies of association of the PRNP genotypes with production traits in sheep are mostly negative (e.g., 
Vitezica et al., 2006), with a notable exception in the Ripollesa breed (Casellas et al., 2007). Concerning dairy sheep populations, to date, studies on associations of the PRNP gene with milk traits support no association in the Lacaune breed (Barillet et al., 2002), the East Friesian breed (De Vries et al., 2005), the Churra breed (Alvarez et al., 2006), the Sardinian breed (Salaris et al., 2007), and Chios sheep (Psifidi et al. 2011). Generally, either the number of genotyped individuals included in these studies was low or only males were included. The aim of this work was to confirm the lack of significant association of PRNP genotypes of ewes with their milk traits (milk, protein and fat yield, protein and fat content) in large data sets where both males and females have been genotyped for the 3 Latxa strains. Compared with other sheep breeds that have applied strong selection to increment the ARR haplotype frequency, Latxa strains are carrying on a different strategy mainly based on decreasing the VRQ frequency.

Data were obtained from Latxa milk-recording programs that have been collecting genealogical and productive data since 1985. Pedigrees were extracted from the national database for each Latxa strain, which included all available ancestors of the animals in the data sets. Milk composition has been routinely collected since 1999. Ewes were born between 1985 and 2009. Summaries of the data for different traits (milk, protein and fat yield, protein and fat content) and strains are presented in Table 1 . The number of equivalent complete generations was computed (Table 1) using PEDIG (Boichard, 2002).

Ewes are exclusively milked after the weaning period. Milk yield was calculated by standardizing lactation to $120 \mathrm{~d}$ using the Fleischmann method. At the start of performance recording, the AT method (ICAR; 2012) was used for the estimation of milk composition, which alternates morning and evening milk recording in each recording visit (Legarra and Ugarte, 2001). Later, it was increasingly substituted by the $\mathrm{AC}$ method that systematically records morning and evening productions (Ugarte, 2007). Fat and protein yields were obtained multiplying contents by milk yield.

The Spanish regulation for sheep forces all replacement animals to be genotyped for the PRNP gene; this genotyping is carried out by the Spanish national reference laboratory. All the ewes in the data file were genotyped for the PRNP gene. Five haplotypes (the most commonly found) were described in the Latxa breed: ARR, AHQ, VRQ, ARQ and ARH. Genotype frequencies in females are shown in Table 2 for the 3 strains.

Two different linear models were used for the analyses. Model I was for milk yield as (Legarra et al., 2005)

$$
\begin{aligned}
y_{i j k l m n}= & \mu+\mathrm{FYS}_{i}+\mathrm{AP}_{j}+\mathrm{NL}_{k}+\mathrm{LF}_{l} \\
& +g_{m}+a_{m}+p_{m}+e_{i j k l m},
\end{aligned}
$$

where $y_{i j k l m n}$ is milk yield; $\mu$ is a constant; $\mathrm{FYS}_{i}$ is a fixed effect of flock-year-season of lambing $(i=1$, 3,800); $\mathrm{AP}_{j}$ is the age at lambing and parity of ewes (fixed effect; $j=1,9$ ); $\mathrm{NL}_{k}$ is the effect of the number of lambs born alive (fixed effect; $k=1,3$ ); $L_{l}$ is a fixed effect of interval between lambing and first milk recording $(l=1,8) ; g_{m}$ is the (random) PRNP effect (genotype of the $m$ th ewe); $a_{m}$ is the random polygenic additive effect of the $m$ th ewe; $p_{m}$ is the random permanent environmental effect of the $m$ th ewe; and $e_{i j k l m}$

\begin{tabular}{|c|c|c|c|c|c|}
\hline Trait & Mean (SD) & $\begin{array}{l}\text { Animals } \\
\text { in data set }\end{array}$ & $\begin{array}{l}\text { Number } \\
\text { of records }\end{array}$ & $\begin{array}{c}\text { Animals } \\
\text { in pedigree }\end{array}$ & $\mathrm{ECG}^{1}$ \\
\hline \multicolumn{6}{|c|}{ Black-faced Latxa from Spanish Basque Country } \\
\hline Milk yield (L) & $158.30(61.48)$ & 27,443 & 82,908 & 49,314 & 3.03 \\
\hline Fat yield (kg) & $9.16(3.25)$ & 12,526 & 28,975 & 24,817 & 2.96 \\
\hline Protein yield (kg) & $9.20(3.13)$ & 12,526 & 28,975 & 24,817 & 2.96 \\
\hline Fat content $(\%)$ & $5.22(0.99)$ & 12,526 & 28,975 & 24,817 & 2.96 \\
\hline Protein content (\%) & $5.16(0.41)$ & 12,526 & 28,975 & 24,817 & 2.96 \\
\hline \multicolumn{6}{|c|}{ Black-faced Latxa from Navarre } \\
\hline Milk yield (L) & $152.59(59.73)$ & 14,681 & 49,793 & 22,481 & 2.85 \\
\hline Fat yield (kg) & $8.61(3.24)$ & 5,284 & 8,568 & 9,876 & 2.76 \\
\hline Protein yield (kg) & $7.48(2.66)$ & 5,284 & 8,568 & 9,876 & 2.76 \\
\hline Fat content $(\%)$ & $5.97(1.05)$ & 5,284 & 8,568 & 9,876 & 2.76 \\
\hline Protein content (\%) & $5.10(0.41)$ & 5,284 & 8,568 & 9,876 & 2.76 \\
\hline \multicolumn{6}{|l|}{ Blond-faced Latxa } \\
\hline Milk yield (L) & $151.27(64.70)$ & 36,000 & 109,864 & 51,511 & 2.96 \\
\hline Fat yield (kg) & $9.61(3.39)$ & 9,617 & 19,414 & 16,743 & 2.91 \\
\hline Protein yield (kg) & $8.42(3.01)$ & 9,617 & 19,414 & 16,743 & 2.91 \\
\hline Fat content (\%) & $5.75(1.06)$ & 9,617 & 19,414 & 16,743 & 2.91 \\
\hline Protein content (\%) & $5.09(0.40)$ & 9,617 & 19,414 & 16,743 & 2.91 \\
\hline
\end{tabular}

Table 1. Data structure for milk, fat, and protein yields, and fat and protein contents for the 3 strains of the Latxa breed

${ }^{1}$ ECG: number of equivalent complete generations. 
Table 2. Genotype frequencies in females for the 3 strains of the Latxa breed

\begin{tabular}{lccc}
\hline & $\begin{array}{c}\text { Black-faced Latxa } \\
\text { from } \begin{array}{c}\text { Spanish Basque Country } \\
(\mathrm{n}=27,443)\end{array}\end{array}$ & $\begin{array}{c}\text { Black-faced Latxa } \\
\text { from Navarre } \\
(\mathrm{n}=14,681)\end{array}$ & $\begin{array}{c}\text { Blond-faced Latxa } \\
(\mathrm{n}=36,000)\end{array}$ \\
\hline AHQ/AHQ & 0.02 & - & - \\
AHQ/ARH & 0.05 & 0.01 & 0.05 \\
AHQ/VRQ & 0.03 & - & 0.01 \\
ARH/ARH & 0.09 & 0.31 & 0.96 \\
ARH/VRQ & 0.09 & 0.03 & 0.49 \\
ARQ/AHQ & 1.58 & 0.11 & 0.36 \\
ARQ/ARH & 3.09 & 6.06 & 11.41 \\
ARQ/ARQ & 49.29 & 47.47 & 38.68 \\
ARQ/VRQ & 2.52 & 1.10 & 0.93 \\
ARR/AHQ & 0.57 & 1.06 & 4.26 \\
ARR/ARH & 1.11 & 36.37 & 31.95 \\
ARR/ARQ & 34.77 & 6.86 & 7.27 \\
ARR/ARR & 5.91 & 0.51 & 1.32 \\
ARR/VRQ & 0.81 & - & 0.09 \\
VRQ/VRQ & 0.05 & &
\end{tabular}

is the random residual effect. The $P R N P$ effect $g_{m}$ was included as genotype (i.e., ARR/ARR, for up to 15 possible genotypes); genotypes were fit as random effects. Due to the size of the data set, this has negligible effects on the final estimates, but allows for testing the overall effect of the PRNP using a likelihood ratio test (e.g., Visscher, 2006).

Model II for protein and fat yield, and protein and fat contents was similar to Model I without the LF effect. A fixed effect, $\mathrm{CTD}_{l}$, of the combination of testdays with known composition $(l=1,11)$ was included (Legarra and Ugarte, 2001).

Analyses included the estimation of variance components associated with $P R N P$, additive polygenic, permanent environment, and residual effects. Analyses were done by single-trait $R E M L$ (one trait and strain at each time) using programs of the BLUPF90 family (Misztal et al., 2002). For each trait, a simplified model was also fitted in which $P R N P$ locus effect was excluded. This model and the full one (with the PRNP genotype effect) were compared on the basis of a likelihood ratio test. The $P$-values were computed considering that the distribution of likelihood ratio test asymptotically is a mixture of chi squared distributions (Visscher, 2006).
Heritability estimates for milk yield and milk quality are given in Table 3 . For the 3 strains, blond-faced latxa, black-faced Latxa from Spanish Basque Country, and black-faced Latxa from from Navarre, the heritabilities ranged from 0.18 to $0.26,0.13$ to $0.24,0.15$ to $0.27,0.15$ to 0.23 , and 0.33 to 0.46 for milk yield, fat and protein yield, and fat and protein content, respectively. These estimates were lower than those obtained in the Lacaune breed (Barillet et al., 2002) and in the Sarda breed (Sanna et al., 1997). However, our estimates are consistent with those reported by Serrano et al. (1996) in the Manchega breed, Othmane et al. (2002) in the Churra breed, De Vries et al. (2005) in the East Friesian sheep breed, and those previously obtained by Legarra and Ugarte (2001) in the black-faced Latxa breed. The partial sampling, the short length of lactation providing a low number of samples by lactation, and the estimation method for fat and protein composition probably influenced the obtained results. In the same way, in different studies (Serrano et al., 1996; Legarra and Ugarte, 2001; Othmane et al., 2002; De Vries et al., 2005), the variability in milking practice and management and poor milk sample collection were also pointed out as reasons for low values of heritability

Table 3. Heritabilities for milk traits in the 3 strains of the Latxa breed

\begin{tabular}{|c|c|c|c|c|c|c|}
\hline \multirow[b]{2}{*}{ Trait } & \multicolumn{2}{|c|}{$\begin{array}{c}\text { Black-faced Latxa } \\
\text { from Spanish Basque } \\
\text { Country }\end{array}$} & \multicolumn{2}{|c|}{$\begin{array}{l}\text { Black-faced Latxa } \\
\text { from Navarre }\end{array}$} & \multicolumn{2}{|c|}{$\begin{array}{l}\text { Blond-faced } \\
\text { Latxa }\end{array}$} \\
\hline & $\begin{array}{l}\text { Due to } \\
\text { PRNP }\end{array}$ & $\begin{array}{l}\text { Additive } \\
\text { polygenic }\end{array}$ & $\begin{array}{l}\text { Due to } \\
\text { PRNP }\end{array}$ & $\begin{array}{l}\text { Additive } \\
\text { polygenic }\end{array}$ & $\begin{array}{l}\text { Due to } \\
\text { PRNP }\end{array}$ & $\begin{array}{l}\text { Additive } \\
\text { polygenic }\end{array}$ \\
\hline Milk yield & $1.0 \times 10^{-3}$ & 0.18 & $1.4 \times 10^{-5}$ & 0.26 & $1.0 \times 10^{-3}$ & 0.22 \\
\hline Fat yield & $7.0 \times 10^{-5}$ & 0.13 & $3.6 \times 10^{-3}$ & 0.24 & $7.7 \times 10^{-4}$ & 0.20 \\
\hline Protein yield & $1.9 \times 10^{-4}$ & 0.15 & $2.9 \times 10^{-3}$ & 0.27 & $9.4 \times 10^{-4}$ & 0.23 \\
\hline Fat content & $3.1 \times 10^{-4}$ & 0.15 & $4.0 \times 10^{-4}$ & 0.17 & $1.8 \times 10^{-4}$ & 0.23 \\
\hline Protein content & $3.5 \times 10^{-4}$ & 0.39 & $8.4 \times 10^{-4}$ & 0.33 & $7.9 \times 10^{-6}$ & 0.46 \\
\hline
\end{tabular}


Table 4. Log-likelihood ratio tests ( $\log \mathrm{L})$ between models with and without PRNP locus random effect for milk traits in the 3 strains of the Latxa breed

\begin{tabular}{|c|c|c|c|c|c|c|}
\hline \multirow[b]{2}{*}{ Trait } & \multicolumn{2}{|c|}{$\begin{array}{l}\text { Black-faced Latxa from } \\
\text { Spanish Basque Country }\end{array}$} & \multicolumn{2}{|c|}{$\begin{array}{l}\text { Black-faced Latxa } \\
\text { from Navarre }\end{array}$} & \multicolumn{2}{|c|}{$\begin{array}{l}\text { Blond-faced } \\
\text { Latxa }\end{array}$} \\
\hline & $\log \mathrm{L}$ & $P$-value & $\log \mathrm{L}$ & $P$-value & $\log \mathrm{L}$ & $P$-value \\
\hline Milk yield (L) & 5.30 & 0.011 & 0 & 0.500 & 14.24 & $8.04 \times 10^{-5}$ \\
\hline Fat yield (kg) & 0 & 0.500 & 6.28 & 0.006 & 1.98 & 0.080 \\
\hline Protein yield (kg) & 0.04 & 0.420 & 2.74 & 0.048 & 3.10 & 0.039 \\
\hline Fat content $(\%)$ & 0.62 & 0.215 & 0.52 & 0.236 & 0.52 & 0.236 \\
\hline Protein content (\%) & 1.56 & 0.105 & 1.80 & 0.089 & 0 & 0.500 \\
\hline
\end{tabular}

compared with those obtained in French Lacaune dairy sheep.

The effect of the PRNP locus on the milk traits was assessed in 2 ways. First, models including PRNP effect or not were compared on the basis of a likelihood ratio test (Table 4). Second, as the PRNP effect was considered to be a random effect, the contribution of the $P R N P$ locus to the additive genetic variance was quantified. The $P R N P$ heritability (Table 3 ) was defined as the ratio of the $P R N P$ effect variance to the phenotypic variance. Regarding milk yield, the model with the PRNP effect had the best fit in black-faced Latxa from Spanish Basque Country and in blond-faced Latxa. Adding the PRNP effect to the model improved the fitting $(P<0.05)$, although the variance due to $P R N P$ was equal to $0.5 \%$ of the additive genetic variance. The average substitution effect of ARR haplotype was computed for milk yield in the 3 strains taking into account the genotypes ARQ/ARQ, ARR/ARQ, and ARR/ ARR. The effect of the ARR haplotype was equal to $0.081,0.021$, and $-0.155 \mathrm{~L}$ in milk yield for black-faced Latxa from Spanish Basque Country, black-faced Latxa from Navarra, and blond-faced Latxa, respectively. The effect of the ARR haplotype is very small confirming a lack of association with milk yield. Including the $P R N P$ effect in the model resulted in a significant likelihood ratio test for fat yield in black-faced Latxa from $\mathrm{Na}$ varra and for protein yield in blond-faced Latxa. Even if the best fitting model included the PRNP effect, its heritability estimates for fat yield $\left(3.6 \times 10^{-3}\right)$ and protein yield $\left(9.4 \times 10^{-4}\right)$ were near zero. The $P R N P$ locus accounts for about 1.5 and $0.4 \%$ of the total genetic (PRNP effect + polygenic additive) variance in fat and protein yield. This is comparable to, for instance, the fraction of genetic variance attributed to a single marker in models for genomic selection, which is in the order of $10^{-5}$ for biallelic markers. We can hypothesize that this variance is due to stochastic linkage disequilibrium between the PRNP locus and the rest of the genome, disequilibrium that is being constantly generated due to selection and drift. Whatever the reason, the effect is so small that has no real implication for breeding purposes.
The results suggest that $P R N P$ genotype contribute little or nothing to the additive genetic variation in milk traits. For breeding purposes, it is unlikely that selection for scrapie resistance will have an effect on milk traits in Latxa breed. The results are consistent with those obtained in other milk sheep breeds.

\section{ACKNOWLEDGMENTS}

Project partially supported by the platform bioinformatics Toulouse Midi-Pyrenees. The authors wish to thank CONFELAC (Confederation of associations of Latxa breed) for the data provided.

\section{REFERENCES}

Alvarez, L., B. Gutiérrez-Gil, F. San Primitivo, L. F. de la Fuente, and J. J. Arranz. 2006. Influence of prion protein genotypes on milk production traits in Spanish Churra sheep. J. Dairy Sci. 89:1784-1791.

Barillet, F., O. Andreoletti, I. Palhiere, X. Aguerre, J. M. Arranz, S. Minery, C. Soulas, J. P. Belloc, M. Briois, G. Fregeat, P. Teinturier, Y. Amigues, J. M. Astruc, M. Y. Boscher, and F. Schelcher. 2002. Breeding for scrapie resistance using Prp genotyping in the french dairy sheep breeds. Proc. 7th World Congr. Genet. Appl. Livest. Prod. 31:683-686.

Boichard, D. 2002. Pedig: A Fortran package for pedigree analysis suited to large populations. 7th World Congr. Genet. Appl. Livest. Prod., Montpellier, France, Commun. No. 28-13.

Casellas, J., G. Caja, R. Bach, O. Francino, and J. Piedrafita. 2007. Association analyses between the prion protein locus and reproductive and lamb weight traits in Ripollesa sheep. J. Anim. Sci. 85:592-597.

De Vries, F., H. Hamann, C. Drögemüller, M. Ganter, and O. Distl. 2005. Analysis of associations between the prion protein genotypes and production traits in East Friesian milk sheep. J. Dairy Sci. 88:392-398.

Díaz, C., Z. G. Vitezica, R. Rupp, O. Andreoletti, and J. M. Elsen. 2005. Polygenic variation and transmission factors involved in the resistance-susceptibility to scrapie in a Romanov flock. J. Gen. Virol. 86:849-857.

Elsen, J. M., Y. Amigues, F. Schelcher, V. Ducrocq, O. Andreoletti, F. Eychenne, J. V. Tien Khang, J. P. Poivey, F. Lantier, and J. L. Laplanche. 1999. Genetic susceptibility and transmission factors in scrapie: Detailed analysis of an epidemic in a closed flock of Romanov. Arch. Virol. 144:431-445.

Hunter, N., J. D. Foster, W. Goldman, M. J. Stear, J. Hope, and C. Bostock. 1996. Natural scrapie in a closed flock of Cheviot sheep occurs only in specific PrP genotypes. Arch. Virol. 141:809-824.

Hurtado, A., A. L. Garcia-Perez, I. Beltrán de Heredia, J. Barandika, A. Sanz-Parra, E. Berroatua, and R. Juste. 2002. Genetic susceptibility to scrpaie in a population of latxa breed sheep in the Basque Country, Spain. Small Rumin. Res. 45:255-259. 
ICAR. 2012. ICAR rules, standards and guidelines for milk recording in sheep. Pages 57-67 in International Agreement of Recording Practices. http://www.icar.org/Documents/Rules\%20and\%20 regulations/Guidelines/Guidelines_2012.pdf.

Legarra, A., P. López-Romero, and E. Ugarte. 2005. Bayesian model selection of contemporary groups for BLUP genetic evaluation in Latxa dairy sheep. Livest. Prod. Sci. 93:205-212.

Legarra, A., and E. Ugarte. 2001. Genetic parameters of milk traits in Latxa dairy sheep. Anim. Sci. 73:407-412.

Legarra, A., E. Ugarte, and I. Beltran de Heredia. 2004. Análisis de asociación y producción de leche en raza Latxa. ITEA 100:127133.

Misztal, I., S. Tsuruta, T. Strabel, B. Auvray, T. Druet, and D. H. Lee. 2002. BLUPF90 and related programs (BGF90). Proc. 7th World Congr. Genet. Appl. Livest. Prod. Montpellier, France. Communication $\mathrm{N}^{\circ} 28-07$.

Othmane, M. H., L. F. De la Fuente, J. A. Carriedo, and F. San Primitivo. 2002. Heritability and genetic correlations of test day milk yield and composition, individual laboratory cheese yield, and somatic cell count for dairy ewes. J. Dairy Sci. 85:2692-2698.

Psifidi, A., Z. Basdagianni, C. I. Dovas, G. Arsenos, E. Sinapis, M. Papanastassopoulou, and G. Banos. 2011. Characterization of the
PRNP gene locus in Chios dairy sheep and its association with milk production and reproduction traits. Anim. Genet. 42:406414.

Salaris, S., S. Casu, and A. Carta. 2007. Investigation the relationship between the prion protein locus and udder morphology traits and milk yield in Sardinian sheep. J. Anim. Sci. 85:2840-2845.

Sanna, S. R., A. Carta, and S. Casu. 1997. (Co)variance component estimates for milk composition traits in Sarda dairy sheep using a bivariate animal model. Small Rumin. Res. 25:77-82.

Serrano, M., M. D. Peréz-Guzmán, V. Montoro, and J. J. Jurado. 1996. Genetic parameters estimation and selection progress for milk yields in Manchega sheep. Small Rumin. Res. 23:51-57.

Ugarte, E. 2007. The breeding program of Latxa breed. Biotechnol. Anim. Husb. 23:97-111.

Visscher, P. M. 2006. A note on the asymptotic distribution of likelihood ratio tests to test variance components. Twin Res. Hum. Genet. 9:490-495.

Vitezica, Z. G., C. R. Moreno, L. Bodin, D. François, F. Barillet, J. C. Brunel, and J. M. Elsen. 2006. No associations between PrP genotypes and reproduction traits in INRA 401 sheep. J. Anim. Sci. 84:1317-1322. 